DOI: $10.7242 / 2658-705 X / 2019.1 .4$

УДК 324

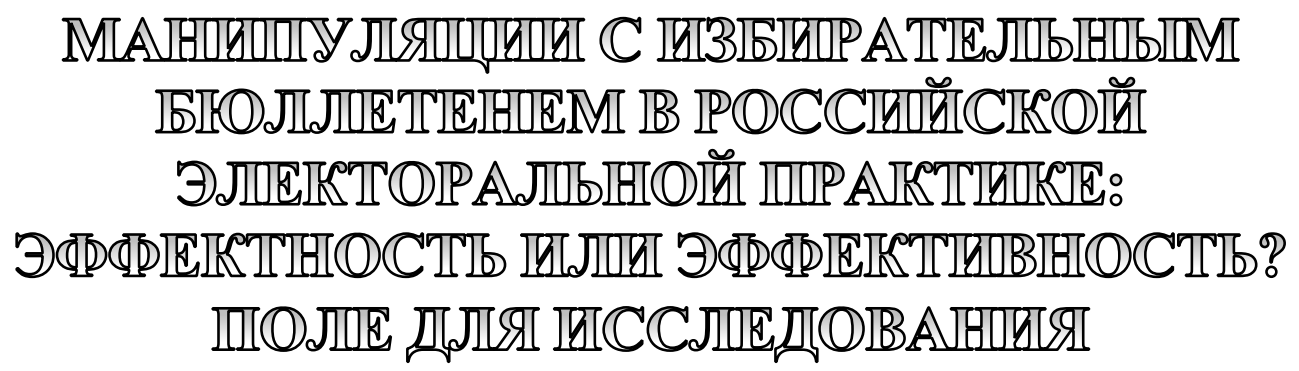

В.С. Ковин, Пермский федеральный исследовательский центр УрО РАН;

Пермский государственный гуманитарно-педагогический университет

Анализируются избирательные манипулятивные технологии, которые используются российскими политтехнологами, кандидатами и партиями, для того, чтобы занять более выгодное положение в избирательном бюллетене: технология «двойников», получение первого места в списке кандидатов, графическое выделение кандидатов и партий. Делается вывод о том, что использование данных технологий в российской электоральной практике не имеет доказанной эффрективности. Оно в большей степени характеризует направленность российской электоральной политики в 2000-е годы на создание дополнительных преференций определенным кандидатам и партиям. В настоящее время применение этих технологий сокращается в связи с сокращением числа конкурентных выборов. Согласно западным исследованиям, эти технологии, хотя и имеют некоторое психологокогнитивное основание, позволяют манипулировать, прежде всего, конформистски настроенными и недостаточно политически подготовленными избирателями. Оценка их влияния на российских избирателей возможна только после проведения масштабных электорально-статистических исследований на основе результатов местных выборов.

Ключевые слова: избирательный бюллетень, выборы, избирательные технологии.

В начале февраля 2018 года некоторый ажиотаж в негосударственных СМИ и в социальных сетях вызвало обнародование ЦИК РФ образца избирательного бюллетеня, который затем использовался для голосования на президентских выборах 18 марта (рис. 1).

Наблюдатели отметили, что «Путин является заметной визуальной доминантой в бюллетене» [16], «кто-то на нем слегка выделяется» [24], «президент выде- ляется в бюллетене» [3] и т.П. При первом взгляде, действительно, фамилия действующего президента визуально выделяется в бюллетене на фоне других кандидатов, бросается в глаза. Происходит это за счет того, что строка с Путиным находится ровно по центру всей композиции, а ее содержание максимально лаконично и короче, чем у других кандидатов. Это создает эффект «свободного пространства» на общем фоне плотно заполненного текста. Были 


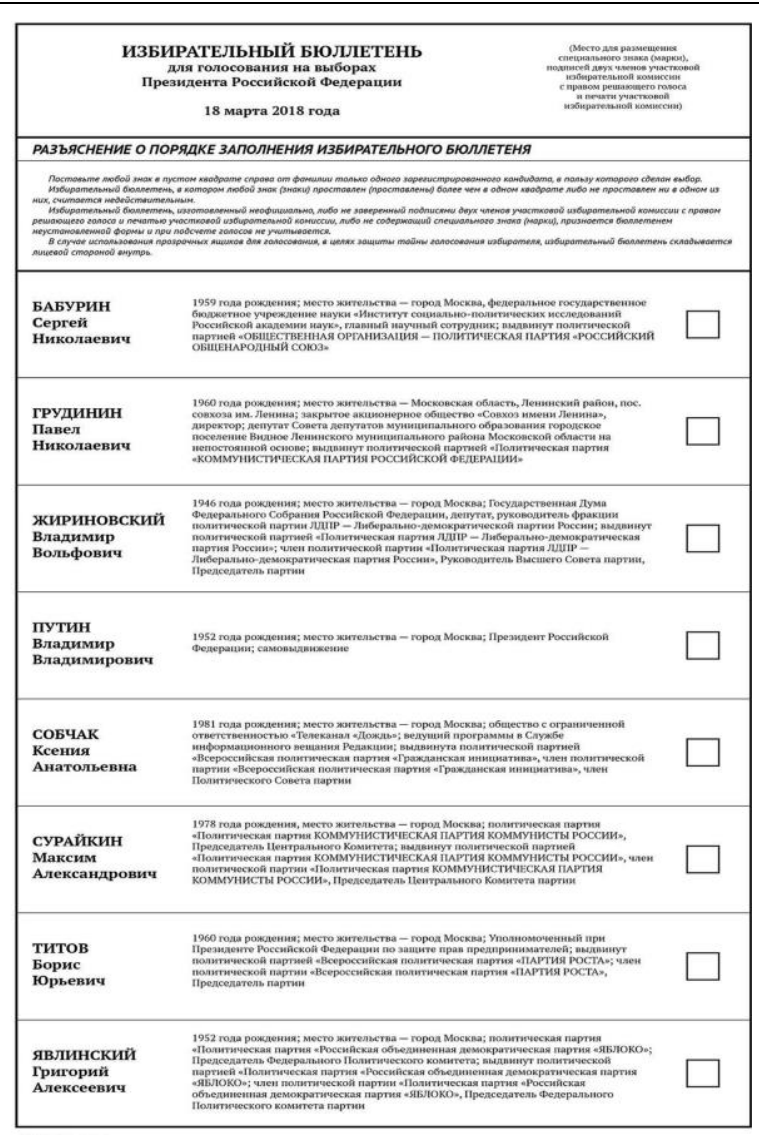

Рис. 1. Образеи бюллетеня на выборах Президента РФ 2018 года [17]

предположения о наличии некоего специального замысла в таком подборе спарринг-партнеров для действующего президента и в его участии в качестве самовыдвиженца: «Семеро и Путин. Избирательный бюллетень как лучшая метафора выборов-2018» [21]. В социальных сетях появились различные шутки и карикатуры, которые как бы доводили логику получившегося бюллетеня до абсурда [6]. На ситуацию пришлось лично отреагировать председателю ЦИК России Элле Памфиловой, которая объяснила, что «У него [Путина] должнность короткая, коротко называется. Так и получилось - больше нечего написать. Год рождения и должность. Никаких отклонений...» [16; 24].

Формально ЦИК РФ поступила в полном соответствии с российским избирательным законодательством. Федеральные законы №67-Ф3 «Об основных гарантиях избирательных прав и права на участие в референдуме граждан Российской Феде- рации» (далее - №67-Ф3 и/или «Об основных гарантиях...») и №19-Ф3 «О выборах Президента Российской Федерации» однозначно устанавливают, что кандидаты располагаются в бюллетене по алфавиту и подробно регламентирует сведения о кандидатах, которые размещаются в нем.

Согласно п. 5 ст. 63 №67-Ф3 избирательный бюллетень должен содержать: год рождения кандидата; наименование субъекта Российской Федерации, района, города, иного населенного пункта, где находится его место жительства; основное место работы или службы; занимаемая должность (как, например, «Президент Российской Федерации» у Владимира Путина) или род занятий; если кандидат является депутатом, то это указывается одновременно с наименованием представительного органа; если кандидат выдвинут избирательным объединением, указывается наименование соответствующей политической партии; если кандидат сам выдвинул свою кандидатуру, то пишется слово «самовыдвижсение» (как и произошло с Владимиром Путиным); в случае необходимости указывается наличие судимости, в т.ч. снятой или погашенной [23]. Если кандидатсамовыдвиженец указал в заявлении о согласии баллотироваться свою принадлежность к политической партии или иному общественному объединению, то в бюллетене указывается их наименование и статус кандидата в них. Путин не стал выдвигаться от «Единой России» и формально эта партия не принимала участие в выборах.

Случай с бюллетенем на президентских выборах 2018 года наглядно продемонстрировал, что избирательный бюллетень может восприниматься не только как официальный документ, в котором фиксируется волеизъявление избирателя, но и как способ визуального предъявления кандидатов своим избирателям, как способ воздействия на их мнение, а также как метафора (символ) всей государственной электоральной политики. 
Сам по себе кейс с «президентским бюллетенем» не стал чем-то исключительным для российской электоральной политики и не вызвал удивления в профессиональной среде. Российский опыт проведения выборов представляет достаточное количество примеров того, как избирательные бюллетени использовались для создания преимуществ одним кандидатам и партиям или для манипуляции избирателями. Российская электоральная практика с середины 90-х и по начало 2010-х годов предписывала ее участникам использовать любые, даже самыми незначительные возможности, чтобы выделить «своего» кандидата (партию) среди прочих или не допустить аналогичного выделения своих конкурентов.

Среди наиболее распространенных приемов манипулирования с использованием избирательного бюллетеня можно выделить:

- использование «кандидатов-двойников», когда перед основным конкурентом в избирательный бюллетень вносится его однофамилец, в надежде на элементарную невнимательность избирателя;

- так называемые «запрограммированные бюллетени», когда каким-то способом один из кандидатов или партия графически, наглядно выделяются на фоне других кандидатов и обращают на себя большее внимание избирателя;

- занятие первого места в списке кандидатов или партий, в надежде, что избиратель отдаст предпочтение именно «первому попавшему» участнику и не будет утруждать себя дальнейшими размышлениями.

Естественно, что эти приемы сами по себе не гарантировали должного результата и, как правило, шли «в пакете» друг с другом и с другими технологиями, но в совокупности, в условиях конкурентной борьбы, каждая из них могла внести свой вклад в победу кандидата.

Одно время среди политтехнологов весьма распространенным и действенным приемом считалось появление в бюллетене «двойников» - кандидатов-однофамильцев основного соперника, с тем, чтобы ввести его потенциальных избирателей в заблуждение и заставить их ошибиться. Формально эта технология основана на том, что согласно законодательству, кандидаты в бюллетене располагаются по алфавиту. Политтехнолог Алексей Швайгерт оценивал, что «по статистике, за счет механической ошибки избирателя при голосовании, однофамилец конкурента может оттянуть на себя, в среднем, от 10 до $30 \%$ его сторонников» [25]. Увлечение этой технологией относится к 2000-м годам.

В настоящее время технология «двойников» используется крайне редко. В значительной степени это связано с тем, что она имеет смысл только на высококонкурентных выборах, которых становится все меньше. С этой технологией связаны определенные финансовые и организационные затраты, а эффекты не очевидны. Кандидаты предпочитают решать свои проблемы и избавляться от серьезных соперников до дня голосования. Так, в Пермском крае за три последних года (2016-2018) среди нескольких сотен местных выборов технологию двойников применяли не более 10 раз.

В 2016 г. в целом на конкурентных выборах в Пермскую городскую думу только в одном из 22 мажоритарных округов против предпринимателя-единоросса Дмитрия Федорова - партией «Справедливая Россия» (СР) был выдвинут «двойник», временно неработающий Денис Федоров. Технология значимого эффекта не дала. Выдвиженец от «Единой России» победил с результатом в $32,76 \%$ голосов, его «двойник» набрал 12,36\%. Второе место заняла кандидат от КПРФ Зинаида Токарева $18,19 \%$, а Александр Фенев от ЛДПР, которому приписывают выдвижение «двойника», всего лишь 13,95\%. Таким образом, выдвижение «второго Федорова» не создало серьезной проблемы для фаворита. 
Таким же, по факту, безрезультатным оказалось выдвижение в 2016 г. «дважды двойника» менеджера одной из коммерческих фирм Журавлевой Натальи Витальевны на местных выборах в Чусовском районе. В первом случае ее выдвинули против действующего депутата от эсеров Журавлевой Натальи Николаевны на выборах в Земское Собрание Чусовского муниципального района по округу №15, что было скорее подстраховкой со стороны конкурентов от ЕР. Депутат Журавлева заняла лишь третье место (146 голосов) и даже без «помощи» двойника (оттянула лишь 60 голосов) не смогла бы опередить кандидата от ЕР (329 голосов). В другом случае, уже на выборах в городскую думу г. Чусового и тоже по №15 округу, та же Наталья Витальевна Журавлева выдвигалась против пенсионерки Зинаиды Михайловны Журавлевой, которая также шла от СР. Справедливоросска, несмотря на острую конкуренцию в округе, смогла победить, набрав 217 голосов $(23,90 \%)$ и опередив на 23 голоса второго кандидата. «Дважды двойник» Журавлева оттянула на себя 73 голоса.

В том же году еще два случая выдвижения однофамильцев были зафиксированы на местных выборах по многомандатным округам в Земские Собрания Кудымкарского (округ №3 - два Петровых) и Косинского муниципальных районов (округ №5 - четыре Федосеевых), но это скорее стечение обстоятельств в связи c распространенностью этих фамилий в данной местности. Каждый из этих кандидатов имел самостоятельные шансы на успех.
В 2017 г. технология «двойников» на местных выборах в Пермском крае использовалась один раз, но очень показательно. На довыборах в городскую думу по округу №1 г. Соликамска Пермского края бюллетень были включены четыре Власовых и два Шилова, а еще один «двойник» не был зарегистрирован. Эти довыборы были крайне важными для местных и региональных властей. На них решалось, чья команда («муниципальная» или «заводская») установит контроль за гордумой. Однако три Власовых отобрали у Светланы Власовой, действующего депутата и директора школы, лишь 10\% голосов. Причем «первая Власова» и первый кандидат в списке, 62-летняя контолёр-приёмщик одного из местных заводов лишь со школьным образованием, набрала 3\% голосов (рис. 2).

В 2018 г. на крайне острых и конкурентных выборах депутатов в Думу объединенного городского округа Краснокамска, где соперничало несколько политических группировок, «двойники» были выдвинуты в трех округах против членов команды лидера регионального «Яблока» и экс-депутата Земского Собрания Ольги Колоколовой. Против нее самой в округе № 3 от КПРФ была выдвинута пенсионерка Наталья Колоколова. Однако ей удалось оттянуть лишь 33 голоса. Сама Ольга Колоколова набрала 248 голосов (26,58\%), что было явно недостаточно для победы над кандидатом от ЕР предпринимателем и также экс-депутатом Земского Собрания Юрием Ильюшенко (457 голосов, 48,98\%). В округе № 4 против яблочника, экс-депутата городской думы и правозащитника Олега Сергеева был выдвинут самовыдвиженец

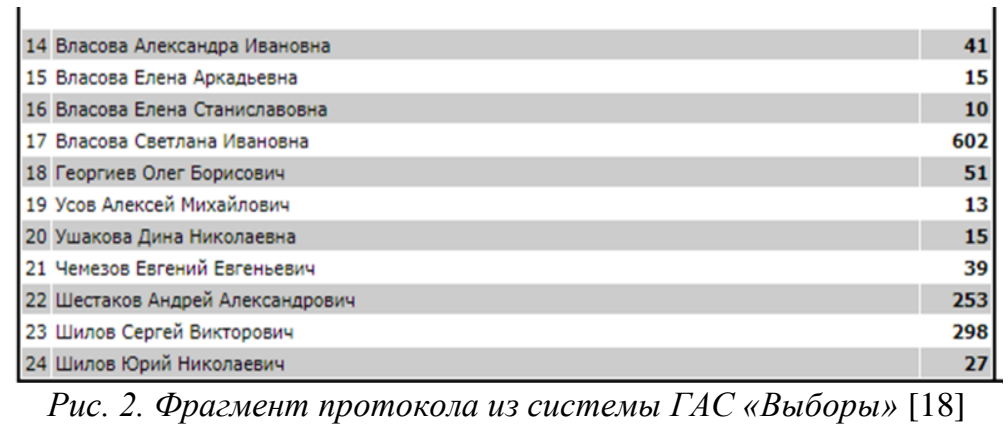


машинист электровоза Андрей Сергеев. «Двойник» смог оттянуть лишь 24 голоса, но и это не понадобилось, поскольку «настоящий» Сергеев набрал лишь 164 голоса и в два раза уступил победившему единороссу. Наконец, в округе № 16 против соратницы Колоколовой и также экс-депутата Земского Совета Светланы Ивановой от ЛДПР была выдвинута пенсионерка Людмила Иванова. Она также не смогла серьезно помешать яблочнице (оттянула лишь 21 голос), но сама Иванова выступила крайне неудачно и набрала лишь 373 голосов $(35,09 \%)$, против 597 (56,16\%) у победителя из партии «Единая Россия».

Таким образом, на примере Пермского края видно, что технология выдвижения «двойников» малоэффективна, даже на весьма конкурентных кампаниях. «Двойники» оттягивают недостаточное количество голосов избирателей (всего несколько процентов), чтобы оказать значимое влияние на результат выборов. По большей части, они выступают как своего рода «подстраховка» со стороны самих политтехнологов и не могут самостоятельно повлиять на победу или поражение основных конкурентов.

Другой весьма значимой дополнительной преференцией для кандидата или партии традиционно считается занятие ими более выгодного места в избирательном бюллетене по сравнению со своими соперниками.

Среди участников выборов и политтехнологов существует устойчивое мнение, что первое место в списке кандидатов в избирательном бюллетене обладает безусловным преимуществом перед всеми остальными («primacy bias» - «смещение первенства», когда кандидат, занимающий первое место в списке по неким правилам, случайным образом или по алфавиту («positional or alphabetical biases» - позиционное или алфавитное смещения голосования), получает немотивированно большую поддержку избирателей). Кандидаты и партии при- лагают определенные усилия для того, чтобы самим занять первое место в избирательном бюллетене или не дать возможности занять его своим наиболее опасным конкурентам. По мнению российских политтехнологов, например, Игоря Минтусова из «НиколоМ», до 1-2\% неопределившихся избирателей способны проголосовать за первый номер в бюллетене [20]. В российской электоральной практике это в большей степени касается расположения в бюллетене политических партий. На выборах по пропорциональной системе места в бюллетене среди партий распределяются в результате жеребьевки, которую проводят члены избирательных комиссий. Партии хотели бы оказаться на первом месте, что, помимо прочего, позволяет обыгрывать это в предвыборной агитации. Другой стороной этой технологии является определение на первое место т. н. «спойлерской» партии, задача которой оттянуть места у основных конкурентов.

На выборах в 2000-2010-е годы в использовании этой технологии особо преуспела партия «Единая Россия». Согласно подсчетам экспертов Комитета гражданских инициатив (КГИ), если собрать все результаты жеребьевок на выборах региональных парламентов, с марта 2006 года по сентябрь 2018 г., то у «Единой России» 86 первых мест из 230 кампаний, или $37 \%$. Вероятность такого события при случайном характере жеребьевок оценивается числом с 18 нулями после запятой. По результатам жеребьевок на выборах представительных органов региональных центров за 2006-2018 гг., у «Единой России» из 124 кампаний первое место в бюллетене в 53 (43\%). По мнению экспертов, «Все эти данные в совокупности заставляют усомниться в случайном характере жеребьевок» [1;7].

В 2014 году на выборах региональных парламентов «Единая Россия» получила первое место в бюллетенях в 5 регионах из 11 , и вероятность такого события при 
честном проведении жеребьевок - 1/103. Аналогичная ситуация и на выборах в горсоветы региональных центров. Однако специалисты отмечают, что «этим странности при жеребьевках не исчерпываются. Так, спойлерская партия «Против всех» за период с сентября 2013 года зарегистрировала всего три списка - в 2013 году на выборах Ивановской областной Думы, а в 2015 году - на выборах Костромской областной Думы и Ивановской городской Думы. И во всех трех случаях у нее первое место в бюллетене. При этом число партий в бюллетене на момент проведения жеребьевок было соответственно 20, 14 и 13. Вероятность такого везения - 1/3640» [2; 9].

В 2016-2017 годах ситуация с жеребьевками по размещению наименования партий в избирательном бюллетене заметно улучшилась. Однако в 2018 г. частота получения «Единой России» первого номера в бюллетене опять стала вызывать подозрения. «Единая России» получила первый номер на выборах в 5 из 16 региональных парламентов (в республиках Башкортостан, Калмыкия и Хакасия, Смоленской и Ярославской областях). Вероятность такого исхода при случайном характере жеребьевок можно оценить примерно как одну двадцатую. [1; 7].

Кроме того, эксперты обратили внимание «на иррациональное сходство результатов жеребьевок на выборах Верховного Совета республики Хакасии 2013 и 2018 годов. В обеих кампаниях у «Единой России» первое место, у «Коммунистов России» - второе, у КПРФ - четвертое, у «Справедливой России» - пятое» $[1 ; 7]$. Однако результаты выборов оказались неутешительными для «партии власти». Она потеряла большинство в парламенте республики (КПРФ - около 31\%, ЕР 25,5\%, ЛДПР - 21\%, «Коммунисты России» $-8 \%, \mathrm{CP}-7 \%$ ).

Возможно, это подтверждает ту гипотезу, что порядок мест в избирательном бюллетене влияет скорее на конформистски на- строенных и на неподготовленных к выбору (неопределившихся) избирателей, но не играет существенной роли при протестном голосовании, когда доминирует мотивация более высокого порядка. Для ее проверки требуется проведение широких статистических исследований по результатам российских выборов, использовавших пропорциональные системы голосования.

В отличие от российской, в западной политической науке данное явление («primacy bias», «positional or alphabetical biases») исследуется достаточно активно. Например, анализ результатов 118 различных выборов 1992 года в американском штате Огайо показал преимущество первого кандидата в бюллетене в $48 \%$ случаев. Причем кандидаты, первые в списке, в среднем получили на 2,5\% больше голосов по сравнению с другими [30]. В других странах этот эффект смещения первого места тоже отмечен.

По мнению ряда исследователей, причины такого смещения имеют когнитивную природу. Исследования по когнитивной психологии утверждают, что ранние элементы того или иного списка имеют большее значение, поскольку они используются в качестве когнитивных маркеров для сравнений с последующими элементами списка. Как следствие, эти ранние предметы получают более сложную обработку, и это приводит к увеличению их значимости [27]. Другие исследователи предположили, что преимущество первого кандидата при голосовании основывается на изначально конформистском подходе избирателя к кандидатам. Этот процесс включает в себя то, что избиратели последовательно положительно оценивают каждого кандидата, чтобы определить причины для выбора этого кандидата. По мере того, как избиратели просматривают список, они выделяют все меньше ресурсов каждому кандидату из-за когнитивной усталости. Как следствие, большее число положительных оценок доста- 
ется для кандидатов в начале списка, увеличивая вероятность их избрания, а кандидаты внизу списка не будут избраны из-за накопления «усталости» избирателя и растраты им положительных оценок [29]. Но при этом эвристическая логика протестно настроенного избирателя вполне может быть обратной [30].

В любом случае речь идет, прежде всего, о тех избирателях, которые полностью или частично определяются со своим выбором непосредственно на избирательном участке. По оценкам российских социологов, такими являются до $1 / 3$ российских избирателей. Брокингтон утверждал, что политически неосведомленные люди, которые голосуют в силу гражданской привычки, испытывают высокий уровень когнитивной усталости, обусловленной неопределенностью выбора кандидата. Эти люди не могут полагаться на свою политическую идентичность, свои политические знания или опросы общественного мнения и, следовательно, когнитивно перегружены решением. Этот тупик в принятии решений, наряду с ограниченными знаниями о кандидатах, способствует использованию решения, основанного на внешних позициях, то есть без существенной информации о кандидатах, которая могла бы помочь при отборе. В результате на часть избирателей влияет позиция в бюллетене, на которой располагаются кандидаты [26]. Однако необходимо уточнить, что речь не идет об избирателях, у которых совершенно отсутствуют какие-либо представления о кандидатах или партиях и для которых единственной стратегией голосования становится простое угадывание. Также следует уточнить, что это касается политически непредопределенных ситуаций, когда победитель (кандидат или партия) заведомо не известны, когда нет доминирующей силы и когда речь не идет лишь о лоялистском «присоединении к победителю».

Данное предположение было фактически подтверждено исследованием, прове- денным другой группой британских ученых на основе анализа базы данных о результатах голосования за более чем 5000 кандидатов от трех ведущих политических партий на местных выборах 2010 года в т. н. «Большом Лондоне» [31]. Оно показало, что среди членов одной партии чаще всего избираются кандидаты, занимавшие в бюллетене первые места среди однопартийцев, чем кандидаты, занявшие второе или третье место (кандидаты от всех партий расположены в бюллетене по алфавиту, избиратель имел три голоса, которые он мог отдать любым кандидатам (рис. 3).

Эксперименты, проведенные другими британскими исследователями, показали, что на совершенно неинформированных избирателей алфавитное смещение («alphabetical bias») может оказывать влияние [28]. Но этот эффект пропадает, как только у избирателя появляется более значимая информация о кандидатах (партиях). Эффект первого места прежде всего может оказывать влияние на местных выборах

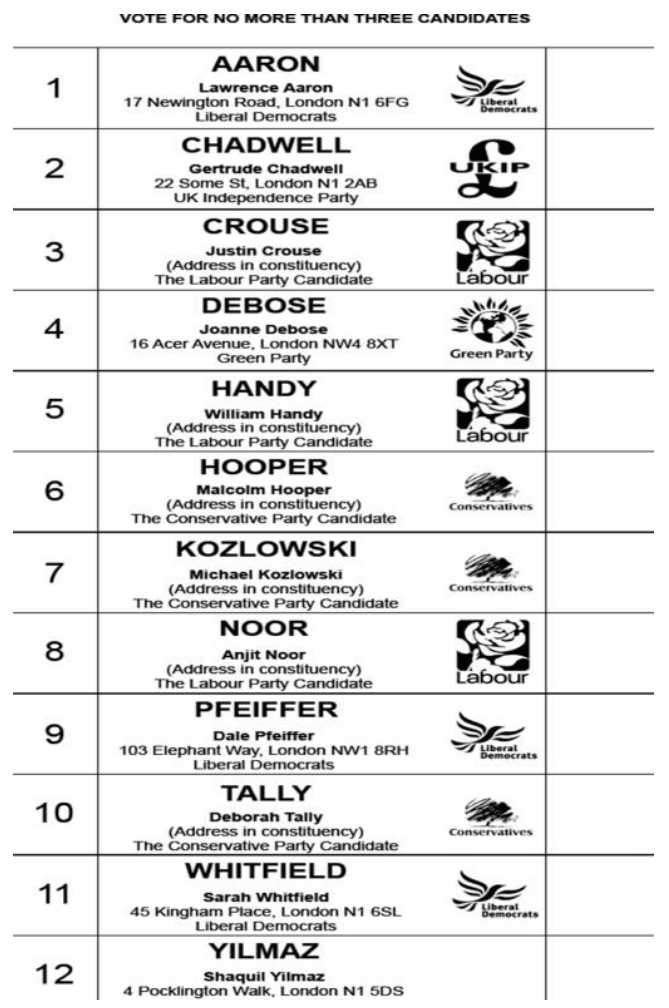

Рис. 3. Фрагмент бюллетеня на местных выборах в Большом Лондоне 2010 2. [31] 
в относительно больших сообществах (городах), когда знания о кандидатах и партиях неполны, или когда избирателю предлагается множественный выбор (многомандатные округа). Также он может работать, когда избиратель определился с предпочтением к той или иной партии или избирательному объединению, но недостаточно знаком с еe конкретными кандидатами и будет готов проголосовать за «первого попавшегося» среди них [28].

В целом, на основании проведенных исследований можно утверждать, что эффект первого места оказывает влияние прежде всего на избирателей, участвующих в выборах скорее в силу привычки, чем в силу политической предпочтений и недостаточно осведомленных о кандидатах и партиях. Ослабление данных элементарных мотиваций для выбора происходит в результате «политического просвещения» избирателей, в активной предвыборной агитации, после введения мотивов более высокого порядка, то есть политического знания.

В России масштабных исследований, посвященных эффекту смещения первого места, к сожалению, не проводилось. Оценить его эффективность достаточно сложно. Однако есть характерные примеры. В 2003 году на выборах в Госдуму «Концептуальная партия «Единение», получившая первую строчку в бюллетене, набрала больше $1 \%$ голосов, хотя никто не знал ни ее лидеров, ни ее программы. «Сыграли роль два фактора: ее могли путать с «Единой Россией», и она была первой в бюллетене», - считал эксперт КГИ Аркадий Любарев [20]. Ряд политтехнологов, регулярно работающих на местных выборах, в экспертных интервью отметили, что стараются подобрать такого «технического» кандидата или спойлера, чтобы он занял первое по алфавиту место в бюллетене в том случае, если существует угроза, что это место займет их основной соперник. Однако проверить то, насколько обоснованны такие предположения, смогут лишь масштабные исследования электоральной статистики местных выборов, особенно на основе многомандатных округов.

Еще в 2003 году Д.О. Парамонов и В.В. Кириченко в работе «Методы фальсификации выборов» писали о том, что визуально «запрограммированный бюллетень» «является самым распространенным» приемом и... «используется практически повсеместно в России». Бюллетень «утверждается таким образом, что один из кандидатов получает существенное визуальное преимущество перед другими кандидатами»: его данные выделяются другим шрифтом, большим кеглем или определенным цветом. Визуально избирательный бюллетень содержит только одного кандидата, остальные кандидаты воспринимаются как «технический текст» [15].

Методы «запрограммированного бюллетеня», наряду с размещением в бюллетене т. н. «Двойников», широко упоминаются в различных справочниках и пособиях по избирательным технологиям и считаются весьма эффективными [25]. Политтехнологи советуют кандидатам, что если есть возможность хоть каким-то образом в избирательном бюллетене дополнительно обратить на себя внимание избирателя, визуально выделиться или подсказать, за кого следует проголосовать, то этим необходимо пользоваться.

Отчасти этому способствует форма самого избирательного бюллетеня, который используется на российских выборах.

Тот тип бумажного избирательного бюллетеня, который применятся на современных российских выборах и в котором избирателю предлагается сделать свой выбор на основе составленного избиркомами списка кандидатов или партий, принято называть «австралийским». Считается, что впервые «австралийский бюллетень» был использован на выборах в штате Виктория в 1857 г. [11]. В конце XIX века он получил распространение в США, а затем и в Европе. 
Российская досоветская практика голосования не имела опыта использования «австралийского бюллетеня». Первоначально она рассматривала письменную форму голосования как некое исключение в случае невозможности лично присутствовать при выборе кандидатур. Ведущую роль играло либо устное голосование, либо голосование «референдумного» типа, выраженное в баллотировке шарами «за» или «против» того или иного кандидата [10]. И только на выборах в Учредительное собрание 1917 года голосование превратилось в процедуру с использованием письменно составленных кандидатских списков, а фактически так называемых «партийных бюллетеней» (каждое избирательное объединение имеет свой бюллетень со списком выдвигаемых ей кандидатов). Причем за партиями и даже избирателями, несмотря на наличие определенных требований к внешнему виду таких списков, сохранялась определенная свобода в их изготовлении и самостоятельном распространении. Фактически они были одним из средств предвыборной агитации, которое можно было получить на митинге, вместе с агитационной листовкой и газетой. Избиратель шел на участок уже практически со сделанным выбором: либо с уже имеющимся на руках нужным списком кандидатов, либо рассчитывая получить его в самой комиссии. На самом участке ему нужно было пройти регистрацию и получить особый конверт для сохранения тайны голосования. Никаких письменных отметок в самом бюллетене, т.е. привычного нам способа голосования, не предусматривалось [10]. При этом требования к форме и содержанию бюллетеня были достаточно просты, бюллетень не имел статус государственной бумаги и не предусматривал никакой специальной защиты от подделок. Такой вид бюллетеня сохраняется в очень многих странах, особенно использующих пропорциональную систему.
«Австралийская» форма, в виде единого списка кандидатов (партий), на одной стороне бюллетеня закрепилась в России в 1995-1996 годах в специальных постановлениях ЦИК РФ. С 1998 года избирательный бюллетень стал цветным. Цветной фон, цветная защитная сетка, плотная цветная бумага с водяным знаками, затем цветной микрошрифт стали способами технической защиты бюллетеней от подделок при помощи копировальной техники [22]. В 2008 г. на думских выборах к ним добавилась специальная марка.

В настоящее время содержание текста и технические характеристики изготовления избирательных бюллетеней достаточно подробно изложены в российском законодательстве, в частности в статье 63. «Бюллетень» №67-Ф3 [23].

В целом, в мировой практике различают два принципиально разных похода к избирательным бюллетеням: официальные бюллетени, напечатанные исключительно государством, и неофициальные бюллетени, которые также могут печататься и распространяться баллотирующимися кандидатами, или партиями, или даже самими избирателями (как, например, во Франции). В первом случае, в том числе и в России, государство берет на себя полную ответственность за изготовление, распространение, использование и учет бюллетеней во время выборов. Бюллетени рассматриваются как государственные официальные документы строгой отчетности. Их форма и содержание утверждаются публичными органами (избиркомами), носят единый универсальный и стандартный характер. Такие бюллетени, как ценные государственные бумаги, имеют несколько степеней защиты от подделок. Считается, что доступ к бюллетеням может иметь только ограниченный круг лиц (члены избирательных комиссий). Избиратели получают их в свои руки лишь на короткое время в сам момент голосования на избирательном 
участке. Незаконные манипуляции с избирательными бюллетенями (их подделка и/или нарушение процедур учета, хранения и выдачи избирателям) рассматриваются как серьезные правонарушения (ч.3 ст.142 УК РФ). Именно по такому наиболее жесткому пути регламентирования пошло российское законодательство, которое фактически запрещает притрагиваться к бюллетеням любым лицам, кроме членов комиссий с правом решающего голоса и избирателям, после того, как они распишутся в списке избирателей за их получение.

По поводу содержания, формы и дизайна бюллетеня принимаются определенные управленческие решения, что, в свою очередь, нередко становится частью политических технологий. В связи с этим избирательный бюллетень, его роль и место в политических процессах вполне могут быть рассмотрены в свете государственной электоральной политики, которая «реализуется посредством специфических органов управления избирательных комиссий, обеспечивается нормативно-правовым регулированием в рамках особой подотрасли права избирательного права, предполагает уникальные политические стратегии и управленческие технологии» [8; 72].

В различных политических условиях роль избирательного бюллетеня в электоральной политике будет отличаться: в одних участники выборов не прочь его использовать в качестве «помощника» для «правильного выбора» избирателя, в других - конкуренты и организаторы выборов стремятся к максимальной политической нейтральности бюллетеня, чтобы минимизировать его влияние на выбор избирателя.

$\mathrm{B}$ российской науке избирательные бюллетени были в основном предметом исследований для специалистов по теории и истории государственного (конституционного) права, где в основном рассматривались его функции, проблемы правового статуса бюллетеня как официального документа, его технической и юридической защиты [9; 45]. Считается, что совершение предусмотренных законом формальных действий с избирательными бюллетенями является одним из механизмов легализации и легитимации результатов выборов.

Однако такой формально-юридический подход упускает собственно политическую сторону голосования. Находясь в кабинке для тайного голосования, избиратель остается один на один с бюллетенем, в котором в самом концентрированном виде, какой только может быть, наглядно представлена политическая ситуация, сложившаяся к данным выборам. Избирательный бюллетень - это наглядное и концентрированное воплощение актуальной политики: от состава участников (а также тех, кто по каким-то причинам в него не попал), со всеми их выпячиваемыми или скрываемыми регалиями и статусами, до попыток какимто образом визуально выделиться на общем фоне кандидатов. Либо, напротив, это наглядная демонстрация намерений организаторов выборов пресекать любые из таких возможных выделений.

Форма и дизайн бюллетеня могут как содержать подсказки для избирателей, выделяя одних кандидатов из общей массы, так и запутывать голосующих, пряча опасных соперников за спинами «спойлеров» и «техников». Выгодный дизайн бюллетеня считается одной из политтехнологических задач, стоящей перед предвыборным штабом кандидата, политической партии, а иногда и самих государственных организаторов выборов. Как официальный документ бюллетень визуализирует государственную политику, является одним из инструментов электоральной и социальной инженерии. В крайних случаях он способен использоваться как средство прямой агитации. В качестве яркого примера такого навязываемого властями выбора («запрограммированного бюллетеня») часто приводят бюллетень голосования по аншлюсу Авст- 
рии 1938 года (рис. 4), дизайн которого недвусмысленно подсказывал, какой выбор ожидается от избирателя.

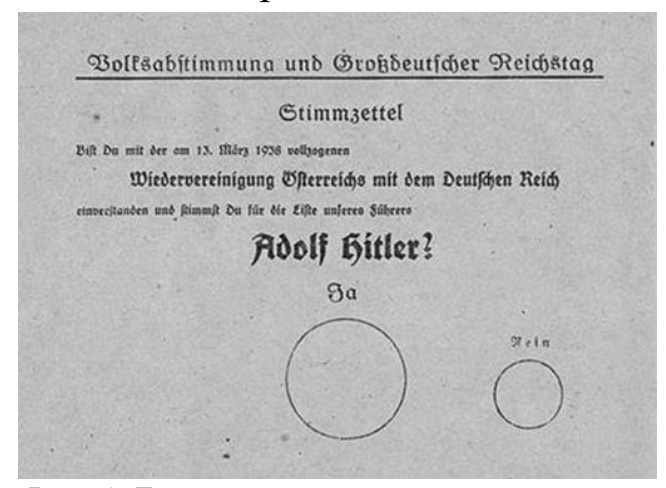

Рис. 4. Бюллетень голосования за анилюс Австрии 1938 года [19]

В российской электоральной практике бюллетень выполняет и коммуникативные функции между кандидатом и потенциальными избирателями. Такое отношение было заложено самими российскими законодателями, которые еще в 90-е годы решили, что бюллетень должен содержать весьма подробную информацию о баллотирующихся кандидатах и партиях. Избирательные комиссии формируют информацию о кандидатах на основе получаемых от них данных. Соответственно у администраторов выборов, кандидатов и их предвыборных штабов появилась возможность как манипулировать самой биографической информацией об участниках выборов (стремиться, чтобы была указана та информация, которая представляет своего кандидата в положительном ракурсе, а конкурента - в отрицательном), так и влиять на внешнюю, визуальную форму подачи этой информации. В таком виде бюллетень становится одним и последним из каналов коммуникации, через который осуществляется передача агитационного сообщения потенциальному избирателю.

Отметим, что во многих странах объем данных о кандидатах, содержащийся в бюллетенях, весьма ограничен и даже скуп. Например, в Норвегии - это ФИО, год рождения и место/район регистрации. В Германии в левой, «мажоритарной части» единого бюллетеня, под именем кандидата указывается лишь род его деятельности - «юрист», «адвокат», «служащий», «публицист» и, не всегда, должность - «старший сотрудник». Примерно такая же ситуация в Великобритании: имя, место жительства и субъект выдвижения. Содержательно или визуально манипулировать такой ограниченной информацией практически невозможно. Иногда дополнительная информация о кандидатах и вовсе отсутствует. Российский же избирательный бюллетень предоставляет весьма широкие возможности политтехнологического творчества в этом направлении.

Однако существовал риск, что этот процесс можно выпустить из-под контроля самой избирательной системы, превратить бюллетень в инструмент наглядной агитации. Постепенно, к середине $2000-x$, в судебной практике был сформулирован запрет на содержание агитации в избирательном бюллетене на том основании, что законодательство запрещает проведение предвыборной агитации в день голосования в помещениях для голосования. Верховный Суд установил, что наличие агитационных материалов в избирательном бюллетене для голосования недопустимо (например, в Калининградской области в 2006 г., «Народная партия» пыталась добиться упоминания одного из своих кандидатов в названиях каждой из региональных групп, которые указывались в соответствующих бюллетенях) [14]. В другом Определении, от 9 марта 2006 г. по делу № 32-Г06-2 Верховный Суд отказал заявителю в требовании внести в избирательный бюллетень в качестве рода его занятий фразу «борьба с коррупцией», поскольку она имеет признаки предвыборной агитации [7; 26.]. Тем не менее, сохраняется практика, когда кандидаты незадолго до выборов «меняют» основное место работы или занимающую должность, чтобы информация об этом в бюллетене выглядела более благозвучно или солидно. 
Некоторые кандидаты путем графического выделения пытаются обратить внимание избирателей на название тех компаний или фирм, в которых они работают и которые могут являться значимыми для избирателя: либо как для работников этих предприятий, либо как градообразующее предприятие на данной территории, либо как связь с предвыборной агитацией, которая шла под брендом предприятия. Выделить в бюллетене заглавными буквами название предприятия - один из способов оставить подсказку, указать на «своих» кандидатов.

На местных выборах, особенно в многомандатных округа, где избиратель имеет несколько голосов, весьма эффективной является «командная технология», когда избирателю сначала в агитационных материалах, а потом в избирательном бюллетене предъявляется команда кандидатов. Естественно, что они должны быть каким-то образом единообразно выделены, например как члены ТОСа, предприятия или избирательного объединения.

Неоднократно в ходе различных российских выборов форма, расположение текста и другие внешние атрибуты избирательного бюллетеня становились предметом судебных разбирательств. Это говорит о чувствительности кандидатов и партий к вопросу их равного обозначения, особенно в условиях конкурентной борьбы. В целом, Конституционный суд РФ придерживается позиции, что положения федеральных законов, устанавливающие требования к форме избирательного бюллетеня, сами по себе не затрагивают конституционных прав граждан. В решениях Верховного суда РФ претензии кандидатов и партий к оформлению бюллетеней или к содержанию в них ошибочной информации, как правило, оцениваются как несущественные, поскольку нельзя однозначно утверждать, что они повлияли на результаты голосования [7, 26-27].
В правоприменительной практике оппоненты усматривали нарушение равенства кандидатов в различных обстоятельствах, имевших отношение к дизайну бюллетеня. Например, кандидат в депутаты Госсобрания Республики Марий Эл в 2004 г. обратил внимание, что расстояние, выделенное для информации о нем, более чем в два раза меньше, чем расстояние, выделенное для информации о другом кандидате. Свое мнение он обосновывал тем, что «избиратели, не знакомые с предвыборными платформами кандидатов, могут сделать выбор в пользу кандидата, который выглядит более солидно с точки зрения объема занимаемого в избирательном бюллетене места» и ссылался на соответствующее заключение специалиста-психолога. Верховный Суд РФ отказал заявителю на том основании, что нормы избирательных законов не содержат требования о том, «чтобы расстояния, выделенные для информации о кандидате в депутаты, были равными», а «площадь полей для отображения сведений о кандидатах в депутаты носит технический характер и не определяет волеизъявление избирателей» [13]. Тем не менее в последующей практике избиркомы стали стараться сохранять равную площадь полей, выделяемую кандидатам (партиям).

Конкуренты не менее чувствительны и к тому, как в бюллетене графически представлены наименования избирательных объединений (партий), от которых выдвинуты кандидаты, или фамилии самих кандидатов. Не нарушаются ли равные условия их представления вследствие выделения этих сведений жирным шрифтом или заглавными буквами, не напечатаны ли наименования политических партий в избирательном бюллетене различными по размеру буквами (прописными или строчными).

Судебные разбирательства по этому поводу были распространены в середине 2000-х годов. Например, в 2008 г. семь кандидатов от КПРФ по мажоритарным окру- 
гам на выборах в депутаты Законодательного Собрания Забайкальского края подали коллективный иск к окружным избирательным комиссиям на том основании, что они нарушили принцип равенства, напечатав бюллетени, в которых наименование партии «Единая Россия» написано заглавными буквами и жирным шрифтом, а партии «Справедливая Россия» заглавными буквами. А наименование партии КПРФ было выполнено без каких-либо выделений. Тем самым, по мнению заявителей, «наименования партий графически изложены не на равных условиях». Они полагали, что данный формат избирательного бюллетеня ставит в более выгодную позицию кандидатов от партии «Единая Россия», так как только ее название бросается в глаза с первого взгляда, и во вторую очередь - кандидатов от «Справедливой России»: а «кандидаты в депутаты от иных избирательных объединений и самовыдвиженцы ставятся тем самым в неравные условия в сравнении с кандидатами от двух названных партий» [12]. Аналогичные случаи графического выделения в бюллетенях наименований партий были и на других выборах.

Суд отказал заявителям на том основании, что, в соответствии с нормами федерального и регионального законов, в текстах бюллетеней для голосования наименования политических партий графически приведены так, как это отражено в уставах этих политических партий. Выделение наименования политической партии не может расцениваться в качестве прямого либо скрытого призыва голосовать за того или иного кандидата [12]. Вскоре почти все ведущие политические партии внесли поправки в свои уставы, в которых графически выделили свои названия. Если обратить внимание на бюллетени последних лет, то наименования партий представлены единообразно заглавными буквами и жирным шрифтом. Хотя на местных выборах иногда происходят «случайные» отступления от этого правила (например, в 2015 г. на выборах в районных советах Самары [5]).

Однако при декларировании либо действительной реализации политическим режимом равных и честных выборов избирательный бюллетень должен быть визуально нейтральным, чтобы сохранить свой политический нейтралитет. Избирательный бюллетень не должен предоставлять какихлибо преференций кому-то из тех, кто в нем перечислен. Режимам, имитирующим конкурентные выборы, такой нейтралитет бюллетеня не выгоден. Отсюда в законодательстве появляются различные лазейки, позволяющие «правильным» кандидатам или партиям выделиться в избирательном бюллетене. Зачастую такие лазейки бывают временными, конъюнктурными, которые срабатывают один или несколько раз, пока декларируемое формально равенство не позволяет воспользоваться ими широкому кругу участников выборов. Тогда они перестают работать как преимущество одних над другими и лазейка закрывается, поскольку расхождение с декларируемыми принципами равенства становится слишком очевидным либо издержки, связанные с ее использованием, непропорционально возрастают. Именно так произошло с графически выделенным отображением в бюллетене официального наименования политической партии, которое должно было выполнять дополнительную функцию привлечения внимания избирателя.

К сожалению, на сегодняшний день отсутствуют сколько-нибудь фундированные конкретными данными исследования, которые оценивали бы степень влияния графического выделения в бюллетене тех или иных данных о кандидатах или партиях на смещение в распределении голосов избирателей. Тем не менее многие российские политтехнологи советуют не пренебрегать такой возможностью.

Можно говорить о том, что помимо своих основных функций избирательный бюллетень, его дизайн, отражает, визуали- 
зирует направленность электоральной политики, которая имеет место в том или ином политическом режиме. Если, в целом, политическая и избирательная системы настроены на создание преимуществ для одних политических акторов в ущерб другим, то это, в том числе, найдет свое воплощение в дизайне избирательного бюллетеня. В некоторых, крайних, случаях это может являться символической демонстрацией политического доминирования, когда власть (или один из иных акторов) настолько уверена в себе, что не опасается негативной реакции оппозиции, общественности, СМИ на всем очевидное неравенство конкурентов, продемонстрированное в избирательном бюллетене (например, на выборах президента Венесуэлы 2018 г., где Мадуро был изображен на бюллетене такое количество раз, сколь- ко объединений его выдвинуло в качестве кандидата на пост президента [4]).

Напротив, демократические и соревновательные политические режимы стремятся избегать любых намеков на нарушение принципов равенства и честной конкуренции. Считается, что текст и форма избирательного бюллетеня должны быть нейтральными по отношению ко всем кандидатам и избирательным объединениям, в нем указанным. Он не может и не должен влиять на волеизъявление избирателя, содержать какие-то подсказки, особо выделять кого-то из кандидатов.

В любом случае, чтобы предметно говорить о действенности указанных технологий, необходимо проведение масштабных электорально-статистических исследований, прежде всего, на основе результатов местных выборов в регионах России.

\section{Библиографический список}

1. Аналитический доклад № 4 по мониторингу выборов 09.09.2018. Споры по итогам регистрации кандидатов и партийных списков, жеребьевки мест в бюллетенях и особенности состава партийных списков на российских выборах 2018 года / сост. А.В. Кынев, А.Е. Любарев, А.Н. Максимов. - М.: Фонд «Либеральная миссия», 2018.

2. Аналитический доклад № 5 по долгосрочному наблюдению выборов 13.09.2015. Процессы, связанные с регистрацией кандидатов и партийных списков; предвыборная агитация / сост. A.B. Кьнев, А.Е. Любарев, А.Н. Максимов. - М.: Комитет гражданских инициатив, 2015.

3. Бобраков-Тимошкин A. «Путин и пустота»: президент выделяется в бюллетене [Электронный ресурс] // Радио Свобода. 08.02. 2018 г. URL: https://www.svoboda.org/a/29027461.html (дата обращения: 20.01.2019).

4. В Венесуэле на бюллетене для выборов Мадуро изобразили десять раз [Электронный ресурс] // РИА Новости. 4.05.2018 г. URL: https://ria.ru/20180504/1519940331.html (дата обращения: 20.01.2019).

5. В Самаре в избирательных бюллетенях только КПРФ не выделена жирным шрифтом [Электронный pecypc] // ИА REGNUM. 3.09.2015 г. URL: https://regnum.ru/news/polit/1962205.html (дата обращения: 20.01.2019).

6. В соцсетях предлагают варианты «правильного» бюллетеня для голосования на выборах президента России [Электронный ресурс] // «Росбалт Like». 08.02. 2018 г. URL: http://www.rosbalt.ru/like/2018/02/08/1680887.html (дата обращения: 20.01.2019).

7. Гетьман Л.С. Основные проблемы практики применения избирательного законодательства, регулирующего создание и использование избирательного бюллетеня // Избирательное право. 2012. - № 2. - С. 24-34.

8. Гришин Н.В. Государственная электоральная политика: предметная область нового научного направления // Каспийский регион: политика, экономика, культура. - Астрахань, 2014. -№ 3. - С. 71-82.

9. Игнатенко В.В., Штурнев А.Е. Словарь-справочник по избирательному праву. - Иркутск, 1999.

10. Минникес И.В. Избирательный бюллетень как документ: историко-правовой очерк // Избирательное право. - 2006. - №1. - С. 67-73.

11. Морозова О.С. Бюллетени для голосования как инструмент избирательной инженерии // Каспийский регион: политика, экономика, культура. - 2014. - №1 (38). - С. 72-78.

12. Определение Верховного Суда Российской Федерации от 9 марта 2006 г. по делу № 71-Г06-10 [Электронный ресурс] // Электронная библиотека «Судебная система Российской Федерации» URL: http://www.sudbiblioteka.ru/vs/text_big2/verhsud_big_34128.htm (дата обращения: 20.01.2019). 
13. Определение Верховного Суда Российской Федерации от 16 октября 2008 г. по делу № 72-Г08-12 [Электронный ресурс] // Электронная библиотека «Судебная система Российской Федерации» URL: http://sudbiblioteka.ru/vs/text_big2/verhsud_big_40680.htm (дата обращения: 20.01.2019).

14. Определение Верховного Суда Российской Федерации от 8 октября 2004 г. по делу № 12-Г04-8 [Электронный ресурс] // Электронная библиотека «Судебная система Российской Федерации». URL: http://sudbiblioteka.ru/vs/text_big2/verhsud_big_30783.htm (дата обращения: 20.01.2019).

15. Парамонов Д. О., Кириченко В. $\bar{B}$. Методы фальсификации выборов. Южно-Российский институт информационных технологий. 2003. [Электронный ресурс] // ЛитМир - Электронная библиотека. URL: https://www.litmir.me/br/?b=14225\&p=1 (дата обращения: 20.01.2019).

16. Путин оказался самым заметным кандидатом в бюллетене на выборах. [Электронный ресурс] // Биби-си. Русская служба. bbcrussian.com. 08.02. 2018 г. URL: https://www.bbc.com/russian/news42988090 (дата обращения: 20.01.2019).

17. Рис. 1. Образец бюллетеня на выборах Президента РФ 2018 года. [Электронный ресурс]. URL: https://tass.ru/politika/4940797 (дата обращения: 20.01.2019).

18. Рис. 2. Фрагмент протокола из системы ГАС «Выборы» [Электронный ресурс]. URL: https://goo.gl/YhnHx2 (дата обращения: 20.01.2019).

19. Рис. 4. Бюллетень голосования за аншлюс Австрии 1938 года. [Электронный ресурс]. URL: https://goo.gl/TZZru8 (дата обращения: 20.01.2019).

20. Рубин М., Ульянова Ж. «Единая Россия» заняла места в бюллетенях вопреки теории вероятности [Электронный ресурс] // РБК. 24.08.2015 г. URL: https://www.rbc.ru/politics/24/08/2015/55 dae9ab9a7947b33a1c8a2b (дата обращения: 20.01.2019).

21. Семеро и Путин. Избирательный бюллетень как лучшая метафора выборов-2018 [Электронный pecypc] // Republic. 08.02. 2018 г. URL: https://republic.ru/posts/89407?fbclid=iwar2583qx6u20cb-pivbpwo7zhx6ppzqf0gmmgx9vk_cdsnx68aicv5b74a (дата обращения: 20.01.2019).

22. Тихонова Л.Е. Изменения в системе защиты избирательного бюллетеня в Российской Федерации (19902000-е годы) // Вестник Кемеровского государственного университета. - 2014. - №1-1(57). - С. 99-103.

23. Федеральный закон от 12.06.2002 № 67-Ф3 (ред. от 27.12.2018) «Об основных гарантиях избирательных прав и права на участие в референдуме граждан Российской Федерации [Электронный ресурс] // Справочная система «КонсультантПлюс» URL: https:/goo.gl/hinSCp (дата обращения: 20.01.2019).

24. ЦИК показал, как будет выглядеть бюллетень на выборах президента. Кто-то на нем слегка выделяется [Электронный ресурс] // Meduza. 08.02. 2018 г. URL: https://goo.gl/tZ3nZJ (дата обращения: 20.01.2019).

25. Швайгерт A. Политтехнологии: ТОП-10 «верняков» на выборах. [Электронный ресурс] // Политтехнолог.py. URL: https://www.polittechnolog.ru/polittehnologii-top-10 (дата обращения: 20.01.2019).

26. Brockington D.A Low Information Theory of Ballot Position Effect. Political Behaviour. - 2003. Vol. 25. - №1. - P. 1-27.

27. Henson R.N.A. Short-term memory for serial order: The start-end model. Cognitive Psychology, -1998. Vol. 36. - P. 73-137.

28. Johnson A.J., Miles C. Order Effects of Ballot Position without Information-Induced Confirmatory Bias // British Politics. - 2011. Vol. 6. - Iss. 4. - P. 479-490.

29. Krosnick J.A. Response strategies for coping with the cognitive demands of attitude measures in surveys // Applied Cognitive Psychology. - 1991. - № 5. - P. 213-236.

30. Miller J.M., Krosnick J.A. The impact of candidate name order on election outcomes. // Political Opinion Quarterly. - 1998. Vol. 62. - P. 291-330.

31. Wood J., Badawood D., Dykes J., Slingsby A. BallotMaps: Detecting name bias in alphabetically ordered ballot papers // IEEE Transactions on Visualization and Computer Graphics. - 2011. Vol. 17(12). - P. 2384-2391. 


\title{
MANIPULATION OF THE BALLOT PAPERS IN RUSSIAN ELECTORAL PRACTICE: EFFICIENCY OR EFFECTIVENESS? SUBJECT FOR RESEARCH
}

\author{
V.S. Kovin \\ Perm Federal Research Centre UB RAS \\ Perm State Humanitarian Pedagogical University
}

The article analyses the manipulation methods used by Russian political technologists, candidates and parties in order to gain a more beneficial position on the ballot paper: the method of "duplicates", obtaining the first position on the list, graphically highlighting certain candidates or parties. The conclusion is made that there is no evidence of the effectiveness of such ballot paper manipulations in Russian electoral practice. Such methods mainly characterize Russian electoral policy to be focused on the development of additional preferences for certain candidates or parties in the 2000s. The use of these manipulation methods is currently decreasing due to the reducing numbers of competitive elections. According to Western research, such methods, although having some psychological and cognitive basis, allow to manipulate primarily by conformist-like and not enough politically competent voters. The impact of these manipulation methods can only be estimated after a large electoral statistical study based on the results of local elections.

Keywords: ballot paper, elections, electoral technologies.

\section{Сведения об авторе}

Ковин Виталий Сергеевич, кандидат исторических наук, старший научный сотрудник отдела по исследованию политических институтов и процессов, Пермский федеральный исследовательский центр УрО РАН (ПФИЦ УрО РАН), 614900, г. Пермь, ул. Ленина, 13А; доцент кафедры истории России, всеобщей истории и археологии, Пермский государственный гуманитарно-педагогический университет (ПГГПУ), 614990, г. Пермь, ул. Сибирская, 24; e-mail: kovinvit@gmail.com 